\title{
LA VENTA DE COSA AJENA EN LA SISTEMÁTICA DEL CÓDIGO CIVIL
}

\section{THE SALE OF SOMEONE ELSE'S PROPERTY IN THE SYSTEM OF THE CIVIL CODE}

\author{
Javier E. Rodríguez Diez \\ JAKOB F. STAGL
}

\begin{abstract}
RESUMEN: Este artículo destaca la subordinación de la responsabilidad del vendedor a la protección que tiene el comprador a propósito de la venta de cosa ajena, a fin de ofrecer una visión crítica del desarrollo de supuestos de invalidez o incumplimiento contractual propuestos por la doctrina y jurisprudencia nacional. Se ilustra desde una perspectiva histórica y comparada la mecánica de las soluciones del Código Civil chileno, identificando dos rasgos diferenciadores claves respecto de otros sistemas jurídicos: la inexistencia de un régimen general de adquisición a non domino y la carga del comprador de defenderse, en colaboración con el vendedor, como requisito para reclamar la responsabilidad de este último.
\end{abstract}

Palabras clave: Compraventa, usucapión, evicción, adquisición a non domino.

ABSTRACT: This article highlights the subordination of the seller's liability to the protection granted to the buyer in the context of the sale of someone else's property. The rationale behind the solutions of the Chilean Civil Code is illustrated through a historical and comparative analysis, identifying two peculiar features which set it apart from other legal systems: the inexistence of a general system of a non domino acquisitions and the burden of the buyer to defend himself with all available means in order to seek responsability from the seller.

Key words: Sale, usucapio, eviction, a non domino acquisition.

\section{INTRODUCCIÓN: LA INCOMODIDAD DE LA DOCTRINA CHILENA ANTE LA VENTA DE COSA AJENA}

El análisis de la compraventa de cosa ajena en Chile en los últimos años ofrece notas que no pueden sino calificarse de paradojales. Por una parte, la doctrina y jurisprudencia aceptan de forma casi unánime, siguiendo el tenor literal de los artículos 1815 y 1824 , que la venta de cosa ajena es válida y que la obligación del vendedor se satisface con la en-

\footnotetext{
Doctor en Derecho, Profesor de Derecho Romano, Facultad de Derecho, Pontificia Universidad Católica de Chile. Dirección postal: Av. Apoquindo 3721, piso 13, Las Condes, Santiago, Chile. Dirección electrónica: javier.rodriguezdiez@uc.cl.

* Doctor en Derecho, Profesor de Introducción al Derecho y Derecho Romano, Facultad de Derecho, Universidad de Chile. Dirección postal: Pío Nono 1, Providencia, Santiago de Chile. Dirección electrónica: jakob. stagl@yahoo.de. Este artículo forma parte del proyecto Fondecyt Regular No 1170316 "The Systematisation of Roman Law", del cual el autor es investigador principal.
} 
trega de la cosa, aun cuando no transfiera el dominio ${ }^{1}$. A pesar de contar con este punto de partida, buena parte de los autores buscan incesantemente otros remedios para que el comprador de cosa ajena pueda dejar sin efecto el contrato, sea alegando la nulidad o el incumplimiento. De esta forma -y aquí viene la paradoja- si bien se sostiene como regla general que la venta de cosa ajena es en sí misma válida y que no supone necesariamente un incumplimiento contractual, se ha propuesto, como excepción que termina por subvertir a la regla, que en una infinidad de situaciones podría alegarse la invalidez o el incumplimiento del contrato.

Las opiniones reseñadas buscan corregir una solución que parece en gran medida contraintuitiva, ya que la función económico-social que se le atribuye de forma generalizada a la compraventa es la transferencia del dominio ${ }^{2}$. Por lo mismo, el comprador debería reaccionar con incomodidad en caso de enterarse que se le vendió un objeto perteneciente a un tercero que no intervino en la operación, aun cuando el verdadero dueño no haya reclamado la cosa. Resulta así casi natural buscar una salida al comprador frente a dicho contrato, sea con recurso a la invalidez o al incumplimiento contractual. Además, esta solución parece ir más allá de una mera intuición, si se considera su amplio respaldo en la experiencia comparada, donde diversos ordenamientos jurídicos europeos e instrumentos de unificación consagran la obligación del vendedor de transferir la propiedad, incluyendo la CISG, DCFR y CESL.

A la luz de lo expuesto, la solución adoptada en nuestro Código Civil suele presentarse como un mero resabio histórico, carente de una lógica clara y cuya existencia difícilmente puede justificarse en nuestra época. Domínguez incluso afirma que "la validez viene más bien inspirada por los precedentes históricos de la regla que por la lógica misma del sistema" ${ }^{3}$, mientras De la Maza indica que este régimen "que tiene una explicación histórica, carece de una justificación dogmática o práctica” ${ }^{3}$. No es de extrañar que, por lo mismo, parte de la doctrina proponga cambios al texto legal, buscando así poner en línea con las tendencias de derecho comparado a una normativa que se presenta como obsoleta.

Los intentos por describir formas de invalidez o incumplimiento en la compraventa de cosa ajena en el derecho chileno pasan por alto las peculiaridades de la mecánica descrita en el Código Civil chileno a propósito de la venta de cosa ajena, y especialmente la forma en que la responsabilidad del vendedor se subordina a la protección del comprador. En este contexto resultan de vital importancia dos elementos de nuestro sistema jurídico que lo distinguen de aquellas jurisdicciones que tratan la venta de cosa ajena como un supuesto

\footnotetext{
1 Véase por ejemplo Domínguez (1979) p. 5; Alessandri (2003) tomo I vol. I, pp. 19-21, 224-244; tomo I vol. II, pp. 659-662; BARCIA (2010) pp. 74-76; AEDO (2015) pp. 5-10 y 35-40. En materia jurisprudencial véase TORO CON BANCO SANTANDER CHILE (2011) considerando $8^{\circ}$. La opinión contraria es sostenida por UGARTE (1970) pp. 151-193 y TRONCOSO y CID (2014) pp. 102-105.

${ }^{2}$ Véase en este sentido Domínguez (1979) p. 1; Troncoso y Cid (2014) pp. 104-105; Torres (2017) p. 305 nota 39; De la Maza (2017) p. 375. Menos receptivo de esta intuición es AlessAndri (2003) tomo I vol. I, p. 20.

3 Domínguez (1979) p. 16. Por su parte, Ugarte (1970) pp. 165 indica que "La ciencia jurídica no ha logrado liberarse del todo de aquellas notas que el Derecho Romano, fundado en consideraciones extrajurídicas y extrarracionales, dejó impresas en la compraventa".

${ }^{4}$ De la Maza (2017) p. 375. En términos similares Aburto y De la Maza (2015) p. 103 y Vidal (2017) p. 244; FERNÁNDEZ (2018) pp. 249 y 251-252.
} 
de nulidad o incumplimiento: (1) la ausencia de una norma general que permita que el comprador se haga instantáneamente dueño de la cosa en caso de estar de buena fe; y (2) la obligación del comprador de defenderse del modo más enérgico posible, en colaboración con el vendedor, como requisito para exigir la responsabilidad de este último (designada aquí con el término 'virilis defensio'). A fin de destacar la relevancia que tienen estos elementos en la configuración de la venta de cosa ajena, en las próximas páginas se propone un enfoque histórico-comparativo que analiza la mecánica que se da entre derechos reales y personales para efectos de configurar el contenido de la obligación del vendedor. Este examen revela que la extensión de las obligaciones del vendedor en Chile está en armonía con la imposibilidad de una adquisición inmediata de la propiedad por parte del comprador, así como con la protección eficaz que obtiene este último en el contexto de una colaboración en la defensa con el vendedor.

\section{PROTECCIÓN DEL COMPRADOR Y REQUISITOS DE LA RESPONSABILIDAD POR EVICCIÓN EN ROMA}

Como hemos reseñado, parte de la crítica a la regulación de la venta de cosa ajena en Chile parte de un supuesto histórico: que la validez de la venta de cosa ajena sería una pesada herencia del derecho romano que no tendría justificación alguna en el derecho actual. Esto obliga a tomar como punto de partida un análisis, aunque somero, del derecho romano clásico. La validez de la venta de cosa ajena en Roma suele afirmarse en las fuentes como una situación prácticamente obvia, a tal punto que Ulpiano habría afirmado que "no existe duda" que puede venderse una cosa ajena ${ }^{5}$. Sin embargo, este punto de partida inevitablemente hace olvidar que estamos ante una solución relativamente aislada. Por ejemplo, en derecho romano tanto el promitente ${ }^{6}$ como el mutuante ${ }^{7}$ se obligan a transferir la propiedad, e incluso el comprador se encuentra obligado a transferir el dominio del precio pagado $^{8}$. Asimismo, la prenda o hipoteca de cosa ajena eran totalmente nulas, dando lugar a la responsabilidad contractual ${ }^{9}$. En todos estos casos el hecho de tratarse de una cosa ajena dará lugar a la responsabilidad contractual, sea por no haberse perfeccionado el contrato o por no haber cumplido la obligación que le imponía el contrato. Así, la validez de la venta de cosa ajena se revela como una figura verdaderamente curiosa y su explicación se torna tanto más urgente.

Normalmente se suelen identificar razones históricas puntuales detrás de la validez de la venta de cosa ajena. Por ejemplo, en sus intercambios comerciales con otros pueblos del Mediterráneo, los romanos habrían enfrentado el problema de que los peregrini no podían tener el dominio quiritario, el cual estaba reservado a los ciudadanos romanos. Asimismo, los propios romanos muchas veces omitían las engorrosas formas rituales dispuestas por el

\footnotetext{
5 Dig. $18,1,28$.

6 Dig. 18,1,25,1. Sobre este texto véase CRISTALDi (2007) pp. 148-160.

7 Dig. 12,1,2,4.

8 Dig. 19,1,11,2; Dig. 19,4,1 pr.

9 Dig. 13,7,2; Dig. 13,7,9 pr.; Dig. 13,7,32; Dig. 22,3,23; Codex Iustinianus 8,15,5.
} 
antiguo ius civile para la transferencia de la propiedad (mancipatio, in iure cessio), conformándose con la mera entrega de la cosa (traditio). En ambos casos, la solución natural habría sido prescindir de la transferencia de la propiedad como una obligación del vendedor ${ }^{10}$.

Si bien esta explicación tradicional da cuenta del origen histórico de la validez de la venta de cosa ajena en Roma, deja pendiente el problema de por qué los juristas no abandonaron esta solución con el paso del tiempo, especialmente cuando se desvaneció la distinción entre romanos y peregrinos, o cuando los modos formales de enajenación cayeron en desuso. La preservación de esta solución sugiere que la jurisprudencia romana desarrolló una mecánica detrás la venta de cosa ajena que va más allá de la mera tolerancia de actos traslativos ineficaces en situaciones puntuales. Esta mecánica consiste ante todo en balancear las obligaciones que nacen del contrato y la protección que recibe el comprador ${ }^{11}$, según se detallará a continuación.

Ante todo, la compraventa en Roma se configuró como un contrato consensual, lo que implicaba que su perfeccionamiento no dependía de la entrega de la cosa vendida. En virtud de la estructura causal de la transferencia de la propiedad por traditio, el único momento en el que resultaba relevante la facultad de enajenar del vendedor era al tiempo de la entrega, no al concluir el contrato. Si al hacer la traditio había perdido la condición de dueño, simplemente no transferiría la propiedad ${ }^{12}$. Estas características permitieron que la venta de cosa ajena no se subsumiera en una hipótesis de nulidad del contrato por falta de perfeccionamiento, como ocurría en los ya nombrados contratos de mutuo, prenda e hipoteca, donde la transferencia de la propiedad o la constitución de derechos reales debían tener lugar al mismo tiempo que la celebración del contrato.

Además de la estructura consensual de la compraventa, un factor clave en la validez de la venta de cosa ajena fue que, si bien el comprador no se hacía dueño de la cosa que recibía, tenía al menos una posesión que, bajo ciertos supuestos, le daba la posibilidad de adquirir el dominio por usucapión (usucapio). Esta institución sirvió de complemento perfecto, en materia de derechos reales, a la posibilidad de celebrar una compraventa con un peregrinus y al progresivo abandono de los modos formales de adquirir el dominio: si bien la compraventa y posterior entrega no transferían el dominio quiritario, el comprador podía estar confiado en adquirir la propiedad de pleno derecho en virtud del transcurso del tiempo. Así, habría resultado abiertamente contrario a los intereses del comprador vincular la validez de la compraventa al hecho de tratarse de un objeto propiedad del vendedor, ya que ello implicaría que el contrato no sería válido, privando al adquirente de una iusta causa usucapionis que le permitiese adquirir por usucapión.

En el contexto de la adquisición por usucapión, existen dos circunstancias que deben tenerse en consideración para dimensionar la protección en términos de derechos reales que obtenía el comprador de la cosa ajena. En primer lugar, el comprador obtendría el pleno dominio solo una vez que transcurriese el periodo de tiempo establecido por la ley, no existiendo en Roma la posibilidad generalizada de que el adquirente de buena fe se hiciese due-

\footnotetext{
10 Aedo (2015) pp. 18-27; Fernández (2018) pp. 29-33.

11 Véase VACCa (2010) pp. 20-21.

12 Dig. 41,3,44,1.
} 
ño de la cosa por esa sola circunstancia y de forma instantánea, como sucede en los supuestos de adquisición a non domino del derecho moderno. En segundo lugar, el comprador de cosa ajena no estaba indefenso en el tiempo intermedio. Si bien el comprador no era dueño para efectos del ius civile, contaba con una importante protección real por parte del pretor, protección que se daba casi exclusivamente cuando el comprador podía usucapir. Considérese ante todo que el comprador que estaba en camino a usucapir y que perdía la cosa a manos de un tercero podía recuperarla por medio de la acción publiciana ${ }^{13}$. Asimismo, el pretor otorgaba una serie de excepciones para enfrentar al dueño de la cosa que injustamente quisiera recuperarla, tales como la exceptio rei venditae et traditae o la exceptio doli ${ }^{14}$. Por lo demás, en cuanto poseedor, el comprador de cosa ajena podía valerse de los interdictos posesorios. Las defensas que hiciera valer el comprador no excluían la posibilidad de adquirir por usucapión, ya que si bien solo podría usucapir en caso de haber recibido la cosa vendida de buena fe -esto es, bajo la creencia de recibirla de quien tenía la facultad de enajenarla ${ }^{15}$ - bastaba que dicha buena fe se verificarse al momento de la tradición ${ }^{16}$. Esto implica que, si el comprador posteriormente se enteraba que el propietario era otra persona, o tenía serias dudas al respecto, ello no obstaba a la adquisición del dominio por usucapión.

La protección del comprador en términos de derechos reales es de vital importancia para comprender la responsabilidad del vendedor en Roma, ya que la procedencia de la acción de compra (actio empti) fue modelada precisamente para cubrir el espectro de situaciones en las cuales el comprador no podía defenderse eficazmente. La doctrina romanística ha puesto de relieve en los últimos años que la obligación de entrega del vendedor se vincula estrechamente con la protección real que se ofrece al comprador ${ }^{17}$. El vendedor será responsable contractualmente frente al comprador allí donde este último no cuente con una protección real eficaz. En principio, esto implica que el vendedor incurría en responsabilidad únicamente si el comprador resultaba evicto ${ }^{18}$, perdiendo la cosa a manos de un tercero sin posibilidad de recuperarla. Esta articulación entre remedios reales y personales condicionaban la actitud que debía asumir el comprador para efectos de hacer valer la responsabilidad del vendedor, ya que debía desplegar lo que los autores del ius commune denominaron una 'virilis defensio', es decir, una defensa vigorosa, echando mano de todas las defensas que tuviese a su disposición para defender su posición ${ }^{19}$, descartándose la responsabilidad por evicción culposa del comprador ${ }^{20}$. Solo si fallaba la protección que se dispensaba al comprador desde el punto de vista de los derechos (por causas no imputables a sí mismo) sea como demandado o como demandante (en este último caso, cuando haya perdido la posesión) podría exigir la responsabilidad de este último.

\footnotetext{
13 Gai 4,36.

14 Véase Rodríguez (2016) pp. 195-214.

15 Gai. 2,42.

16 Dig. 41,1,48,1. Véase este punto Zimmermann (1996) p. 280 y Salinas (2004) pp. 474-476.

17 Vacca (2010) pp. 23-29; Cristaldi (2007) pp. 10-13; 121 y ss.; Guida (2013) pp. 35-58.

18 Dig. 19,4,1 pr.

19 Sobre este régimen véase WACKE (1992) pp. 164 y ss.; GuIDA (2013) pp. 156-167.

20 WACKE (1992) pp. 183-196.
} 
Para que se activara el régimen de la evicción, el comprador debía ser demandado judicialmente, sin que pudiera darse lugar a la responsabilidad por la mera alegación de propiedad de un tercero ${ }^{21}$. Una vez requerido judicialmente, el comprador debía notificar al vendedor ${ }^{22}$, quien podía colaborar en la defensa. El vendedor no sería responsable contractualmente si el comprador no completó la usucapión por su propia culpa ${ }^{23}$, si perdió la posesión de la cosa por su propia culpa ${ }^{24}$, si no citó al vendedor ${ }^{25}$, si no compareció él mismo al juicio ${ }^{26}$ o si restituyó la cosa espontáneamente a quien creía dueño ${ }^{27}$. Además, en tanto el comprador cuente con la publiciana para recuperar la cosa que perdió a manos de un tercero, no tendrá la actio empti contra el vendedor ${ }^{28}$, la cual solo será procedente si el comprador es finalmente vencido ${ }^{29}$. Huelga decir que el transcurso del plazo para adquirir por usucapión excluía la responsabilidad del vendedor.

La relación entre la protección del comprador y la procedencia de la actio empti se manifiesta la responsabilidad inmediata del vendedor cuando sea imposible usucapir. Un caso elocuente al respecto se verifica cuando el vendedor entrega deliberadamente un objeto ajeno, ocultando dicha circunstancia al comprador, ante lo cual este último puede ejercer la actio empti aun antes de ser evicto. Si bien la venta en este caso parece entenderse válidamente concluida ${ }^{30}$, el texto que contiene esta solución (Dig. 19,1,30,1) relaciona la procedencia de la responsabilidad del vendedor a la infracción a la bona fides que supone exponer deliberada y clandestinamente al comprador a una eventual pérdida de la cosa ${ }^{31}$. Sin profundizar en la abundante discusión doctrinaria en torno a esta solución ${ }^{32}$, cabe destacar que la entrega deliberada de una cosa ajena configura una forma de furtum, en cuanto el vendedor actúa deliberadamente al margen de la voluntad del dueño ${ }^{33}$. A su vez, ello impide adquirir por usucapión, por cuanto las cosas furtivas son res inhabilis al efecto ${ }^{34}$. Esta completa desprotección desde el punto de vista real explicaría en parte por qué los juristas deciden recurrir a la buena fe para hacer valer la responsabilidad del vendedor, pese a que aún no ha sido evicto ${ }^{35}$.

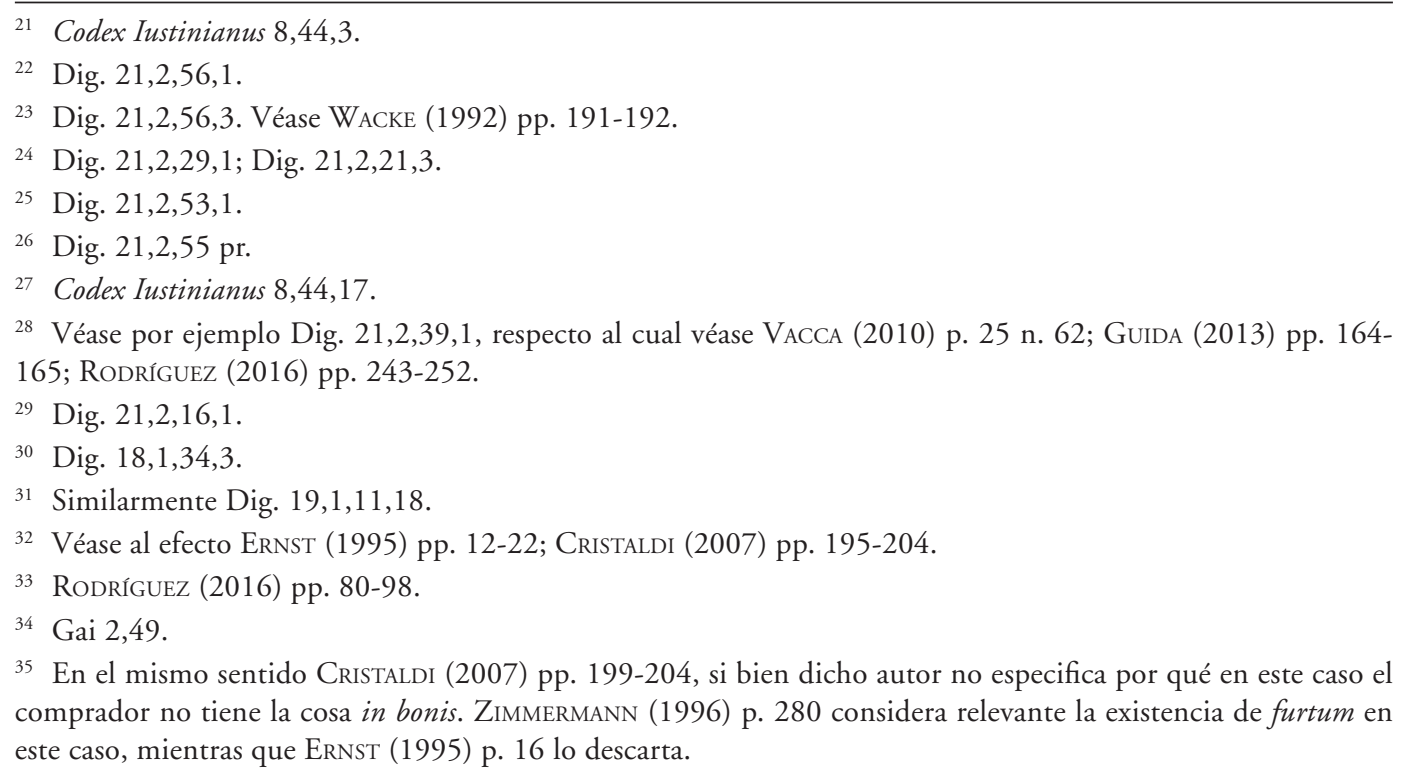


De lo dicho se desprende que en Roma la responsabilidad del vendedor llegaba hasta donde el comprador tuviese a su disposición herramientas para defender su posición, articulando un sistema en que vendedor y comprador deben defender la posición de este último si el vendedor pretende librarse de responsabilidad. La posición del comprador se ve así reforzada no solo por la protección que tiene en términos de derechos reales, sino por el incentivo que tiene el vendedor en colaborar a la defensa. Por estas consideraciones, el régimen de la venta de cosa ajena en Roma se muestra no como un mero fruto accidental del devenir histórico, sino como un consistente sistema que articula la relación entre la protección del comprador y la responsabilidad del vendedor. Ante la incertidumbre que genera la disputa sobre una cosa, la respuesta primaria del derecho romano viene dada desde el punto de vista de los derechos reales, y solo en subsidio de ellos, una vez que fracasa la defensa (y el perjuicio eventual pasa a ser una realidad) ${ }^{36}$ se permite echar mano a los mecanismos para hacer valer la responsabilidad contractual del vendedor ${ }^{37}$.

\section{ADQUISICIÓN A NON DOMINO Y FIN DE LA VIRILIS DEFENSIO EN LA GÉNESIS DE LA OBLIGACIÓN DE TRANSFERIR LA PROPIEDAD}

El delicado equilibrio del derecho romano clásico entre la protección del comprador y la responsabilidad contractual del vendedor se vería alterado en siglos sucesivos por diversos desarrollos en materia de derechos reales. Pueden advertirse innovaciones relevantes en este punto ya en la legislación de Justiniano, quien al regular la usucapio (para bienes muebles) y la longi temporis praescriptio (para inmuebles) estableció plazos considerablemente más largos para adquirir el dominio, que van de los tres a los cuarenta años en situaciones calificadas ${ }^{38}$. Sin embargo, el cambio más decisivo para efectos de la función de la usucapio o praescriptio tuvo lugar siglos después. Como queda dicho, en el derecho romano bastaba una buena fe inicial del adquirente para efectos de la usucapión. Sin embargo, dicha solución repugnaba a los canonistas, quienes veían en ella una amenaza para la salvación en caso de que el adquirente se haga dueño a pesar de su mala conciencia. Es por ello que Inocencio III decretó que este tipo de comportamiento equivale a un supuesto de furtum, siendo constitutivo de pecado mortal. Se puso así fin a la posibilidad de adquirir por usucapión en caso de mala fe superviniente, naciendo la regla de derecho canónico mala fides superveniens nocet (la mala fe superviniente sí perjudica) ${ }^{39}$. Este cambio trajo consigo un debilitamiento adicional de la posición del comprador: no solo podía estar expuesto a esperar por décadas para adquirir el dominio, sino que en dicho tiempo podría advertir que el vendedor no era dueño al momento de la entrega, impidiendo (o al menos dificultando aún más) su adquisición por medio de la prescripción adquisitiva.

\footnotetext{
36 Bergmann (2010) pp. 35-36 y 49.

37 Dig. 21,2,17. En relación a la responsabilidad contractual y la posición real del adquirente véase CRISTALDI (2007) pp. 161-166 y VACCA (2010) pp. 26-28, n. 67.

38 Codex Iustinianus 7,31,1; 7,39,1,1; Inst. Just. 2,6 pr.

39 Véase Salinas (2004) pp. 477-481 y Stagl (2011) pp. 546-547.
} 
A medida que la función de la prescripción adquisitiva se debilitaba, surgió una nueva institución en materia de derechos reales que ponía al comprador a salvo de manera instantánea: la llamada 'adquisición a non domino'. Esta institución tiene sus orígenes en el derecho germánico ${ }^{40}$, e implica la adquisición inmediata de la propiedad por parte de quien recibe la cosa bajo la creencia de obtenerla de quien tiene facultad para enajenarla. En términos dogmáticos, ello envuelve una ruptura total con la tradición romanista, pero en términos prácticos supone más bien una diferencia técnica con contornos menos radicales. La institución de la adquisición a non domino exige, al igual que la usucapio romana, la buena fe del adquirente, pero la adquisición del dominio opera de forma instantánea, sin que tenga que transcurrir un plazo determinado. Estamos así frente a una especie de usucapión con plazo reducido a cero ${ }^{41}$, donde el problema de la mala fe superviniente desaparece. Eventualmente, esta institución fue consagrada en el Código Civil francés, el cual estableció en su art. 2279 la famosa regla 'possession vaut titre'. Otros códigos consagrarían reglas similares, dando una mayor o menor protección al adquirente de buena $\mathrm{fe}^{42}$.

Un último cambio en materia de derechos reales fue la consolidación de sistemas consensuales de transmisión de la propiedad, particularmente en el Código Civil francés, el cual consagró que la mera voluntad de los contratantes bastaba para transferir el dominio ${ }^{43}$. Esto implicaba una revisión a la estructura del contrato de compraventa, la cual a partir de esta innovación estaba dotada de efectos reales y no meramente obligacionales. Al igual que los otros contratos en los que el efecto real coincidía con el perfeccionamiento del contrato -como el mutuo o la prenda- ello significaba que la compraventa no podía ser válidamente concluida por quien no fuese dueño de la cosa, lo cual se consagró expresamente en el art. 1599 del Code. Existe así un vínculo inmediato entre el surgimiento de sistemas consensuales y la configuración de la obligación del vendedor de transferir la propiedad ${ }^{44}$.

Si bien la consagración de sistemas consensuales de enajenación tuvo como consecuencia la nulidad de la venta de cosa ajena, jurisdicciones con otros sistemas de transferencia dominical consagraron igualmente la obligación del vendedor de transferir la propiedad, como el Código Civil austriaco de 1811 ( $\$ 433$ inc. $1^{\circ}$ ), el Código Civil holandés de $1838^{45}$ y el BGB alemán de 1900 (\$\$ 433, 434, 440 y 442). Un factor crucial detrás de esta evo-

\footnotetext{
40 STAGL (2011) p. 535.

41 STAGL (2011) pp. 530 y ss.

42 Código Civil austriaco, $\$ 367$; Código Civil holandés de 1838, art. 2014; BGB $\$ \$ 932$ y 935; Código Civil italiano de 1942, art. 1153; Nuevo Código Civil holandés 3:86, 88.

43 Código Civil francés (1804) arts. 711, 938, 1138, 1583.

44 Para la gestación de la nulidad de la venta de cosa ajena y su relación con el sistema consensual de enajenación, véase Petronio (1991) pp. 169-195. Para otros sistemas consensuales que consagran la nulidad de la venta de cosa ajena, véase Código Civil Belga, arts. 711, 938, 1138, 1583; Código Civil Italiano de 1865, art. 1125 y 1448; Código Civil italiano de 1942, arts. 922, 1376 y ss., 1470, 1476; Código Civil portugués de 1967, arts. 408 y ss., 874, 879, 892, 1316. RABEL (1936) pp. 313-314 enfatiza la importancia de los diversos sistemas traslativos en la configuración de las obligaciones del vendedor. Crítico respecto de esta idea es FeRNÁNDEZ (2018) pp. 100-101.

45 Si bien el Código Civil holandés de 1838, art. 1507 consagró -en lo que parece ser una imitación irreflexiva del sistema francés- la nulidad de la venta de cosa ajena, la jurisprudencia terminó por entender que el vendedor estaba obligado a transferir la propiedad, lo que se consagró en el nuevo Código Civil holandés 7:9 y 7:15. Véase en este punto HijMa (2007) pp. 261-279.
} 
lución parece ser la consagración de normas de adquisición a non domino, las cuales implicaban que en un mayor número de situaciones el comprador adquiriría el dominio pese a haber recibido la cosa de manos de un no propietario. En efecto, mientras mayor sea la protección al adquirente de buena fe, mayor será la tendencia a obligar al vendedor a transferir la propiedad, como sucede en Holanda y Alemania, donde el vendedor podrá en múltiples casos transferir el dominio aun cuando no tenga la facultad de enajenar la $\operatorname{cosa}^{46}$. A la inversa, en sistemas donde la adquisición a non domino otorga una menor protección, no tiene sentido cargar al vendedor con la obligación de transferir la propiedad, dando en su lugar al comprador la posibilidad de adquirir la propiedad por medio de la prescripción adquisitiva, como sucede, por ejemplo, en el Código Civil español (arts. 463, 1475, 1480 y 1955).

Estas diversas innovaciones en materia de derechos reales tuvieron además un impacto inmediato en la actitud que debía asumir el comprador como presupuesto para perseguir la responsabilidad del vendedor. Inicialmente, los autores del ius commune exigían lo que denominaron una 'virilis defensio' por parte del comprador, en línea con el derecho roma$\mathrm{no}^{47}$. Este régimen resultaría inexplicable o inútil bajo la regla de la mala fides superveniens nocet, pero más aun con la consagración de la nulidad de la compraventa o de una obligación de transferir el dominio. Como consecuencia de lo anterior, muy pocos Códigos Civiles consagraron la virilis defensio como carga del comprador, la cual incluso se encuentra ausente -en una palmaria inconsistencia- en algunos códigos en los que la obligación del vendedor se satisface con la entrega, como es el caso de España ${ }^{48}$.

La evolución anteriormente descrita revela la íntima conexión entre la protección del comprador y las obligaciones que se imponen al vendedor. Sin embargo, este vínculo a menudo se pierde de vista en el análisis doctrinario. Ello puede achacarse a la tendencia sistemática que domina la ciencia jurídica desde el siglo XIX -y muy característicamente a la pandectística alemana- que ha buscado construir una compleja sistematización del derecho privado por medio de la creación de innumerables compartimientos en los que encasillar diversos problemas jurídicos, olvidando su íntima vinculación con otras materias ${ }^{49}$. Las distorsiones que ello puede traer consigo se aprecian en la materia bajo análisis, donde el problema de la compraventa de cosa ajena se suele analizar sin referencia a la situación del comprador en términos de derechos reales. Este es particularmente el caso de Ernst Rabel, el cerebro tras la Convención de Viena, para quien los aspectos de la compraventa vinculados a los derechos reales eran de modesta importancia práctica ${ }^{50}$. No es de extrañar, por lo tanto, que la Convención de Viena de 1980, sobre los Contratos de Compraventa Internacional de Mercaderías (CISG), establezca la obligación de transferir el dominio (arts. 30 y 41),

\footnotetext{
46 Sobre el impacto de esta regulación en las obligaciones del vendedor, véase RABEL (1936) p. 314; WACKE (1992) p. 202; Hijma (2007) pp. 264-265; VACCA (2010) pp. 35-39; FernándeZ (2018) pp. 250-251.

47 Zimmermann (1996) pp. 302-303; Bergmann (2010) p. 52. Véase por ejemplo la Partida V, título V, ley 36.

48 Rabel (1936) p. 314; Wacke (1992) pp. 196-204; Zimmermann (1996) pp. 303-304; Guida (2013) pp. 169 y ss. Como indican estos autores, se pueden encontrar excepciones a este fenómeno, por ejemplo, en derecho sudafricano y en el antiguo Código Civil argentino.

49 Véase en este punto Stagl (2016) pp. 241, 246-247.

50 Rabel (1936) pp. 27-32.
} 
aunque sin regular los efectos reales del contrato, materia que se entrega al derecho internacional privado de los estados miembros.

Entre los instrumentos de unificación jurídica cabe también mencionar al Draft Common Frame of Reference (DCFR), que también somete al vendedor a la obligación de transferir la propiedad ${ }^{51}$. Sin embargo, el DCFR sí regula la transferencia de la propiedad, estableciendo un sistema causal de título y modo y normas generales de protección de terceros adquirentes ${ }^{52}$, relevando además al comprador de una virilis defensio ${ }^{53}$, todo lo cual hace más adecuado que el vendedor quede obligado en estos términos. Lamentablemente, esta regulación conjunta de remedios reales y personales se perdió en el proyecto de normativa común de compraventa europea (CESL), la cual sigue la opción de la Convención de Viena al excluir una regulación sobre los efectos reales de la compraventa, imponiendo al mismo tiempo al vendedor la obligación de transferir la propiedad ${ }^{54}$. Sin embargo, este proyecto es profundamente tributario del DCFR, por lo que las opciones adoptadas a propósito del contrato de compraventa parecen apoyarse en la regulación 'durmiente' en materia de transferencia de la propiedad ${ }^{55}$. En este contexto, la obligación de transferir la propiedad que recae sobre el vendedor del CESL es consistente con las normas sobre protección de terceros de buena fe del DCFR, aunque resulta indudablemente problemático que estas últimas no se hayan consagrado expresamente en el CESL.

\section{PROTECCIÓN REAL DEL COMPRADOR Y OBLIGACIONES DEL VENDEDOR EN EL CÓDIGO CIVIL CHILENO}

\subsection{PRESCRIPCIÓN ADQUisitiva y VIRILIS DEFENSIO EN CHILE}

Como se desprende de los párrafos precedentes, el derecho comparado ofrece abundantes ejemplos de sistemas en los que el vendedor se encuentra obligado a transferir la propiedad, siendo comprensible que la doctrina chilena se vea tentada a incorporar también esta obligación. Sin embargo, al tenor del análisis ofrecido, la gran pregunta que queda por responder es si la obligación que se le impone al vendedor resulta armónica con la protección que se le otorga al comprador.

Desde ya, es necesario advertir que nuestra legislación carece de los dos elementos que en mayor medida han influido en la experiencia comparada al fijar la obligación del vendedor de transferir la propiedad: un sistema consensual de transferencia del dominio y reglas generales de adquisición a non domino. Por lo que toca al sistema de transferencia de la propiedad, Bello consagró un esquema causal, en virtud del cual la compraventa tiene exclusivamente consecuencias en la esfera obligacional, lo que ha sido uno de los principales puntos en base a los que la doctrina chilena ha justificado la validez de la venta de cosa

\footnotetext{
51 DCFR IV. A. - 1:202 y IV. A. - 2:101.

52 Véase DCFR II. - 6:107 y DCFR VIII. - 3:101.

53 DCFR IV. A. -2:305.

54 CESL (Proyecto) art. 2 letra (k), art. 91 letra b) y art. 102.1.

55 STAGL (2016) pp. 257-259
} 
ajena $^{56}$. Por otra parte, el Código Civil chileno contempla supuestos excepcionales y limitados de adquisición a non domino ${ }^{57}$.

En el Código Civil chileno el comprador de cosa ajena normalmente solo tendrá una expectativa de hacerse dueño en base a la prescripción adquisitiva -la cual tiene en el Código Civil un ámbito de aplicación considerablemente más amplio que la usucapio clásica- lo que, unido a una virilis defensio, condiciona las obligaciones del vendedor en términos análogos a aquellos del derecho romano. El art. 1815 constituye el punto de partida, señalando que "La venta de cosa ajena vale, sin perjuicio de los derechos del dueño de la cosa vendida, mientras no se extingan por el lapso de tiempo"58. Solo la prescripción adquisitiva pondrá al comprador a salvo del verdadero dueño y librará al vendedor de responsabilidad ${ }^{59}$, gozando de una presunción de buena fe al efecto (art. 707). Pero el comprador de cosa ajena no solo tiene una expectativa de hacerse dueño, sino que tiene además una serie de herramientas para defender su posición en el intertanto, incluyendo la acción publiciana (en caso de perder la cosa a manos de un tercero), las acciones posesorias ${ }^{60}$ y la presunción de dominio del poseedor (art. 700).

A la protección que goza el comprador debe agregarse la obligación de saneamiento de la evicción, según se verá a continuación. En efecto, el vendedor está obligado a "amparar al comprador en el dominio y posesión pacífica de la cosa” (art. 1837). En términos prácticos, esto implica que el comprador no puede simplemente perseguir la responsabilidad del vendedor si se entera que la cosa es ajena, si duda del dominio de su antecesor o sufre turbaciones solo de hecho ${ }^{61}$, lo que está en armonía con la suficiencia de una buena fe inicial para efectos de la prescripción adquisitiva (art. 702$)^{62}$. El único remedio preventivo que se le otorga al comprador es la exceptio evictionis imminentis del CC $1872^{63}$. Para que se verifique el saneamiento de la evicción, el comprador debe ver perturbada ${ }^{64}$ su posesión, normalmente en el contexto de un juicio de dominio, frente a lo cual debe citar al vendedor, que será responsable en caso de no comparecer y si la cosa es evicta (arts. 1843 y 1855). El vendedor tiene así no solo el incentivo, sino que una verdadera obligación de defensa. En caso de que el vendedor comparezca, se seguirá el juicio en su contra, sin perjuicio de la posibilidad del comprador de intervenir para la conservación de sus derechos (art. 1844). El Código Civil recoge en este punto con una claridad casi sin paralelo en la experiencia comparada la exigencia de una 'virilis defensio', ya que el vendedor será responsable solo si el comprador se valió de todos los medios jurídicos a su disposición para

\footnotetext{
56 Alessandri (2003) tomo I vol. I, pp. 20-21, 225-226, 241-242.

57 Véase por ejemplo los arts. 890, 1490, 1491, 2303 y 2428 inc. $2^{\circ}$.

58 Para las posibles fuentes de este artículo véase CATTÁn (1982) pp. 622-623.

59 Alessandri (2003) tomo I vol. I, pp. 225-227.

60 TORO CON BANCO SANTANDER CHILE (2011) considerando $11^{\circ}$.

61 Alessandri (2003) tomo I vol. II, p. 660 y tomo II vol. I, pp. 58-61. Véase TORO CON BANCO SANTANDER CHILE (2011) considerandos $4^{\circ}$ y $11^{\circ}$.

62 Véase sobre este artículo Salinas (2004) pp. 484-489.

63 Véase De la Maza y Torres (2015) pp. 811-814. Sobre sus orígenes: Ernst (1995) p. 60-75; Guida (2013) pp. 158-161.

64 Para el concepto de 'perturbación’ véase DE LA MaZA (2017) pp. 349-379.
} 
retener la $\cos ^{65}$. Por ejemplo, si el vendedor citado no concurre a defender la cosa vendida, no será responsable de la evicción en caso que "el comprador haya dejado de oponer alguna defensa o excepción suya, y por ello fuere evicta la cosa" (art. 1843 inc. $3^{\circ}$ ). Otro tanto sucede si "el comprador perdió la posesión por su culpa, y de ello se siguió la evicción" (art. 1846 No 2). El Código Civil chileno describe así a un comprador que debe defender celosamente su posición, en colaboración con el vendedor, si quiere eventualmente hacer valer la responsabilidad de este último, lo cual dista sustancialmente, por ejemplo, de la regulación del BGB, donde el comprador que se entera de la ajenidad de la cosa puede entregarla voluntariamente al vendedor o a quien cree dueño, pudiendo a continuación rescindir el contrato ${ }^{66}$.

La interacción entre derechos reales y personales aquí descrita da lugar a una provechosa colaboración que la doctrina rara vez advierte. En la gran mayoría de los casos, comprador y vendedor tendrán intereses coincidentes: en la medida que el comprador defienda con eficacia su posición, el vendedor se librará de la responsabilidad por evicción. Esta coincidencia de intereses se articula en una defensa eficaz si se considera es el mismo vendedor citado quien debe liderar la defensa, por lo que su derrota al defender los intereses del comprador traerá consigo su responsabilidad contractual. La defensa es tan fuerte como su eslabón más débil, lo que condiciona la responsabilidad del vendedor: si el comprador no se molesta en defenderse, no podrá demandar al vendedor; si el vendedor no comparece a asumir la defensa, será responsable; si comparece, solo será responsable si fracasa en la defensa. El comprador encuentra así su mayor protección en el condicionamiento de la responsabilidad del vendedor al fracaso de su defensa. Se trata en todo caso de un sistema que beneficia a ambos contratantes, ya que el vendedor solo será responsable si la pretensión del tercero resulta exitosa.

La colaboración descrita condiciona inevitablemente la dinámica de los juicios relativos a la venta de cosa ajena. En caso que al comprador le surja una duda respecto a la calidad jurídica de su antecesor, normalmente no tendrá interés en levantar él mismo una controversia sobre el dominio si no ha aparecido en escena un tercero que se pretenda dueño, trayendo sobre sí una reivindicación que sería solo eventual y frustrando sus propias posibilidades de adquirir por prescripción adquisitiva. Ello está en armonía con la irrelevancia de la mala fe sobrevenida para efectos de la prescripción adquisitiva. Por lo mismo, en la jurisprudencia sobre la venta de cosa ajena normalmente encontramos al comprador haciendo causa común con el vendedor, y solo excepcionalmente el comprador que no ha sido evicto persigue la nulidad o la responsabilidad del vendedor, como sucede en caso de

\footnotetext{
${ }_{65}$ Este punto escapa a la atención de UGARTE (1970) p. 173 cuando afirma "la incompatibilidad entre la obligación que tiene todo mero poseedor de restituir la cosa a su dueño, y la obligación que presuntamente emanaría de un contrato de venta, de entregar la posesión tranquila y pacífica”. En efecto, el comprador no debe sin más restituir la posesión a quien se pretende dueño, sino que debe valerse de todas las defensas y excepciones disponibles para repelerlo. Para defender su postura, el autor se ve obligado a ofrecer una interpretación alternativa de las normas aquí citadas (pp. 187-190).

${ }^{66}$ BGB $\$ 351$ en relación con los $\$ \$ 440$ y 442. Véase en este punto WACKE (1992) pp. 157-159 y ERNST (1995) pp. 191 y ss.
} 
errores manifiestos o fraudes ${ }^{67}$. Resulta así por regla general irrelevante el grado de certeza que tenga el comprador sobre la ajenidad de la cosa, elemento que Ugarte considera decisivo para efectos de demandar el incumplimiento contractual ${ }^{68}$. En efecto, incluso un comprador que llegue a la convicción de haber recibido una cosa ajena al vendedor puede adquirir el dominio y repeler eventuales pretensiones del dueño de la cosa invocando la prescripción. Los intereses del comprador y del vendedor se encuentran así casi invariablemente alineados, lo que se ve reforzado por la exigencia de una virilis defensio.

\subsection{El Código Civil Chileno frente a los llamados de Reforma}

La regulación del Código Civil chileno da cuenta de un sistema que no es un mero resabio histórico cuya justificación se pierde en el pasado, sino que una regulación que protege al comprador de modo coherente y funcional. A continuación toca dilucidar si este sistema resulta preferible frente aquellos que surgen en la experiencia comparada. Parte de la doctrina nacional ha abogado por un cambio legal en la materia, en términos tales que se le imponga al vendedor la obligación de transferir la propiedad ${ }^{69}$, o que se subsuma este régimen especial de responsabilidad dentro de una noción unitaria de incumplimiento por falta de conformidad ${ }^{70}$ conforme al modelo de la CISG o de los PLDC ${ }^{71}$. Sin embargo, las consideraciones desarrolladas precedentemente permiten advertir que la consagración de una obligación de transferir la propiedad en la compraventa debería además implicar una modificación en el régimen general de evicción (suprimiendo la virilis defensio) y en materia de los derechos reales. Este último cambio podría consistir en adoptar el modelo de transferencia consensual de la propiedad (como sucede en Francia o Italia) y/o en introducir en términos amplios la posibilidad de adquirir a non domino por parte del comprador de buena fe (como en Holanda o Alemania). Por cuanto queda dicho, de no implementarse alguna de estas modificaciones, la obligación del vendedor de transferir la propiedad sería discordante con la regulación en materia de derechos reales, imponiendo una carga excesivamente gravosa. La posibilidad de reforma se presenta así como posible, aunque profundamente invasiva respecto de las instituciones del Código Civil chileno atendida la entidad de los cambios requeridos y su ajenidad a la tradición jurídica nacional.

Debemos preguntarnos además si acaso un cambio legal traería consigo verdaderas ventajas respecto a la actual regulación. Por una parte, una reforma de estas características difícilmente tendría un impacto positivo en cuanto a claridad de las soluciones jurídicas. Tómese como ejemplo la regla de la nulidad generalizada de la compraventa de cosa ajena

\footnotetext{
${ }^{67}$ Respecto de un caso de error, véase por ejemplo GARCIA Y ALBORNOZ CON NAVARRETE Y BANCO SANTIAGO (2001), donde las bases del remate diferían de aquello que realmente se vendía. Para la hipótesis de fraude, véase Domínguez (1979) pp. 17-22, analizado infra. Un caso excepcional lo constituye TORO CON BANCO SANTANDER CHILE (2011), donde la demanda del comprador contra el vendedor fue rechazada precisamente por no oponer una virilis defensio.

68 Ugarte (1970) p. 184.

69 Domínguez (1979) p. 22; Aburto y De la Maza (2015) pp. 102-103; De la Maza (2017) p. 375.

70 De la Maza, Pizarro y Vidal (2017) p. 52; Vidal (2017) pp. 255-259 y 272-275; Cárdenas y Reveco (2018) pp. 51-55 y 59-71; De la Maza y Vidal (2018) p. 262. Para el derecho español véase Morales (2017) pp. 17 y $29-55$.

${ }^{71}$ Véase el art. 86 de los PLDC en De la Maza, Pizarro y Vidal (2017) p. 95.
} 
en el Código Civil francés, la que ha acarreado una serie de problemas que han hecho evidente la imposibilidad del codificador francés de prever y regular todas las consecuencias asociadas a esta sanción ${ }^{72}$. Por ejemplo, se debieron introducir distinciones y subdistinciones para determinar cuándo la venta sí es válida, como sucede en la venta de cosas que el vendedor declara que todavía no entran en su patrimonio (art. 1585), y en el caso de ventas sucesivas a dos personas distintas, se abandonó la solución de una transferencia consensual para favorecer a quien primero entró a poseer la cosa (art. 1141). Además, la doctrina ha discutido largamente si la venta de cosa ajena se encuadraría bajo una hipótesis de nulidad absoluta o relativa, con todas las consecuencias prácticas que ello trae consigo ${ }^{73}$. Las complicaciones no son menores respecto a las normas que regulan la adquisición a non domino, las cuales se encuentran a menudo entre las más controvertidos de diversos códigos, suscitando espinosos problemas relativos ante todo a sus presupuestos y ámbito de aplicación ${ }^{74}$.

Por otra parte, la necesidad de reforma legal no resulta en modo alguno evidente desde el punto de vista de la eficaz protección del comprador. Muy por el contrario, como se ha indicado, al exigir una auténtica derrota del comprador como presupuesto para hacer valer la responsabilidad del vendedor se privilegia la cooperación entre los contratantes, tendiente a evitar la pérdida de la cosa. El comprador que tenga dudas sobre su dominio o se vea amenazado por un tercero va a tener una cuota de incerteza, que puede o no ser justificada. En Chile se hace responsable al vendedor solo si esa incerteza fue justificada, privilegiando así que operen los remedios puestos a favor del comprador en materia de derechos reales por medio de una colaboración de los contratantes en la defensa.

La exigencia de una virilis defensio favorece una colaboración entre comprador y vendedor que se vislumbra incluso en los sistemas jurídicos donde el vendedor debe transferir la propiedad: por ejemplo, el Código Civil holandés (7:16) consagra una obligación del vendedor que implica una forma de asistencia en el juicio donde se disputa la propiedad del comprador ${ }^{75}$, y el Código Civil italiano (art. 1485) establece que el comprador que no cite al vendedor y pierda la cosa sin razón suficiente no puede hacer valer la responsabilidad del vendedor, del mismo modo que si reconoce espontáneamente el derecho de un tercero sobre la cosa y no prueba que existían razones suficientes para impedir la evicción. Estas reminiscencias del sistema romano de evicción demuestran que no es sencillo invertir la dinámica de colaboración entre comprador y vendedor, ya que a menudo solo al final de un juicio podrá establecerse cuál es la situación del comprador, pudiendo contribuir el vendedor a la obtención de un resultado positivo. En este sentido, el hecho que el art. 41 de la CISG haga responsable al vendedor a partir de "cualesquiera derechos o pretensiones de un tercero" supone una desprotección del vendedor frente a todo tipo de alegaciones infunda$\mathrm{das}^{76}$. Ligeramente menos gravosa resulta la sugerencia de hacer responder al vendedor "sin

\footnotetext{
72 Petronio (1991) pp. 180-186, 194; Bergmann (2010) p. 47.

73 Fernández (1994) pp. 42-47; Díez-Picazo (2010) pp. 60-61; Alessandri (2003) tomo I vol. I, pp. $242-$ 243; FERNÁNDEZ (2018) pp. 98-99.

74 STAGL (2011) pp. 556 y ss.

75 Véase Hijma (2007) p. 275.

76 Rodríguez (2011) p. 5; Morales (2017) p. 53. La redacción es similar al BGB $\$ 453$ y al Uniform Commercial Code 2-312. Schlechtriem (1984) pp. 6-31 busca acotar la norma a pretensiones claramente infun-
} 
tener que probar de modo inequívoco la existencia del derecho"77 o ante cualquier "derecho o pretensión razonablemente fundada" (DCFR IV. A. -2:305).

Lo anterior revela así una de las principales complicaciones que siguen de excusar al comprador de una virilis defensio: la fijación de un baremo abstracto a partir del cual sea aceptable que se haga directamente responsable al vendedor. Existe una cuota de ingenuidad en la idea de asumir que el vendedor debe rendirse ante cualquier pretensión medianamente fundada de un tercero (o incluso ante la sospecha de que dicho derecho exista, aun cuando no se haya deducido en juicio), como si un juicio eventual fuese una mera formalidad, pasando así por alto que el comprador puede invocar en su favor la presunción de dominio, la presunción de buena fe, la prescripción adquisitiva y, en cualquier caso, dejar a su vendedor a cargo de la defensa, hallándose así en una posición privilegiada de cara al tercero que invoca un derecho. El transcurso del tiempo de prescripción consolidará el derecho del comprador sobre la cosa, siendo eventual cualquier perjuicio asociado a su ajenidad hasta que ello se verifique. En este contexto, resulta un error equiparar esta situación a aquella de los vicios materiales de la cosa, subsumiéndolos en una noción general de incumplimiento por falta de conformidad ${ }^{78}$, ya que en el caso de los defectos materiales existe un perjuicio actual para el comprador, mientras que en la mayoría de los casos de venta de cosa ajena el perjuicio será eventual, concretándose solo con la efectiva pérdida de la $\operatorname{cosa}^{79}$.

Relevar al comprador de una virilis defensio en los términos descritos por la CISG o el DCFR implica no solo poner de cargo del vendedor el riesgo del traspaso de la propiedad, sino que incluso del mero riesgo de interposición demandas, impidiéndole participar en la defensa del comprador y sin esperar que se constate la efectiva existencia del derecho del tercero ${ }^{80}$. Si lo que se busca es propender a la colaboración de las partes al perseguir los objetivos del contrato, nada resultará más desilusionante para el vendedor que un comprador que no haga valer las herramientas que le da el ordenamiento jurídico ${ }^{81}$, amparándose en su lugar en cláusulas generales cuya aplicación al caso concreto difícilmente puede apreciarse de antemano, tales como la referencia a una 'pretensión razonablemente fundada' de un tercero. La solución adoptada por la CISG busca ante todo que el vendedor tenga que asumir la defensa con independencia del fundamento de la pretensión del tercero ${ }^{82}$, lo que se consigue de todas formas con el régimen de citación a evicción. Por lo demás, no deja de ser elocuente respecto de la consistencia de las soluciones del CISG el que se haya sugerido que el comprador, como parte de su deber de mitigar el daño, debe adoptar medidas razo-

\footnotetext{
dadas, frívolas o irritantes, añadiendo sin embargo a continuación: "Yet difficulties are to be expected in the provision's practical application".

77 Morales (2017) p. 52.

78 ERnSt (1995) pp. 208-209.

79 Véase Wacke (1992) pp. 158, 176 y 199, y en particular Bergmann (2010) pp. 34-37 y 75-79.

80 El riesgo es tan evidente que SCHLeChtriem (1984) pp. 6-31 considera que la norma podría dar lugar a que un comprador arrepentido conspire con un tercero para que lo demande.

81 Véase WACKe (1992) pp. 200-201 para el caso en que el vendedor llega a acuerdo con el dueño de la cosa, pese a lo cual es demandado por el comprador.

82 Schlechtriem (1984) pp. 6-30 y 6-31; Magnus (2010) p. 446; Rodríguez (2011) pp. 5-6.
} 
nables para defenderse ${ }^{83}$, o que las partes directamente puedan limitar la obligación del art. 41 del CISG en términos tales que el vendedor se vea únicamente obligado a asumir la defensa frente a terceros ${ }^{84}$. Además, la regla del art. 41 es tan amplia que cubre incluso aquellos casos en que el comprador se habría hecho dueño por adquisición a non domino ${ }^{85}$, con lo que en definitiva se hace responsable al vendedor por la mera existencia de una demanda y se relega al olvido el problema de la transferencia del dominio. Queda así de manifiesto cuán problemático puede resultar consagrar una obligación de transferir el dominio, que por lo mismo ha sido acogida en términos estrictos en pocas jurisdicciones, mientras que predominan fórmulas intermedias, en las cuales se conservan sistemas de evicción ${ }^{86}$-aunque sea mitigados- que conviven con la obligación de transferir la propiedad, difuminando así los contornos de esta última.

Como contraste a estas manifiestas complicaciones, no está de más señalar que los problemas prácticos a los que da lugar la venta de cosa ajena en Chile son de reducida entidad, sin que se verifique la inseguridad jurídica que acusa parte de la doctrina ${ }^{87}$. La principal discordancia dogmática que suele plantearse es si la venta de cosa ajena es subsumible dentro de hipótesis de nulidad, discordancia que por lo demás tiene un impacto práctico limitado si se considera que casi invariablemente quien pide la nulidad no es el comprador, sino el tercero que se pretende dueño de la cosa, quien tiene a su disposición de todas formas la acción reivindicatoria y que perseguirá la nulidad ante todo para invocar plazos de prescripción más extensos ${ }^{88}$. Por lo demás, si de certeza jurídica y previsibilidad se trata, el requisito para hacer valer la responsabilidad del vendedor que contempla el Código Civil chileno se basa en un supuesto fácilmente discernible, como es la evicción del comprador, lo que contrasta con las cláusulas generales anteriormente descritas, tales como la existencia de una 'pretensión razonablemente fundada' de un tercero.

\subsection{Hipótesis generales de nUlidad y la VENTA de COSA AJENA}

Parte de la doctrina nacional ha buscado relevar al comprador de recurrir a las normas sobre evicción como presupuesto para hacer valer la responsabilidad del vendedor, recurriendo en primer lugar a las normas sobre nulidad. En efecto, no debe descartarse de antemano que una compraventa de cosa ajena pueda coincidir con una causal de nulidad absoluta o relativa. Por ejemplo, en caso de que la venta de cosa ajena sea un contrato prohibido por las leyes, estaremos frente a una hipótesis de objeto ilícito en los términos del

\footnotetext{
83 Magnus (2010) p. 447; Rodríguez (2011) p. 6. Para Alemania véase Wacke (1992) pp. 158-159.

84 Rodríguez (2011) p. 9.

85 Magnus (2010) pp. 446-447. En Holanda el problema no está resuelto, según indica Hijma (2007) pp. $264-265$.

86 Véase Wacke (1992) pp. 161-164; 199-202; Hijma (2007) p. 27; Guida (2013) pp. 206-208; FernándeZ (2018) pp. 258-264.

87 VIDAL (2017) pp. 244 y 267.

88 Véase por ejemplo SAAVEDRA CON N.N. (1996); MARTÍNEZ CON MARTÍNEZ (1996); VALDÉS CON BÓRQUEZ (2005); Microsoft Corporation con López (2008); PeÑa con SANHueza (2011); Fuenzalida con Fuenzalida (2015); MiCHELL CON MiCHELL (2018).
} 
art. $1466^{89}$, o si existe un desacuerdo respecto a la identidad de la cosa vendida se verificará un caso de error ${ }^{90}$. Sin embargo, no resulta consistente con la regulación actual encuadrar de forma generalizada la venta de cosa ajena en diversas causales de nulidad ${ }^{91}$. Este sería el caso, por ejemplo, si se califica como nula por falta de voluntad la venta concluida en virtud de mandatos falsificados o revocados ${ }^{92}$. Esta solución tiene como principal inconveniente el hecho que parece igualmente aplicable a cualquier otro caso de venta de cosa ajena, sea que alguien invoque un mandato terminado, que se exceda de un mandato vigente o que quien concurre a celebrar el acto actúe a nombre propio ${ }^{93}$. En todos estos supuestos se da por igual un supuesto de inoponibilidad por falta de concurrencia ${ }^{94}$, no existiendo propiamente un 'vicio de la voluntad', ya que no se afecta la voluntad de quien concurre a celebrar el acto ${ }^{95}$, como sucedería, por ejemplo, en un supuesto de demencia.

Otro tanto cabe señalar con relación a la tesis de quienes señalan que la venta de cosa ajena puede estar viciada por el error esencial. De la Maza y Torres consideran que este supuesto sería aplicable cuando el dominio en el vendedor "se ha integrado al contrato en calidad de 'esencial" "96. Sin embargo, la generalidad de este criterio los haría aplicables a prácticamente cualquier hipótesis de venta de cosa ajena, ya que solo en raras ocasiones el comprador afirmará que no le resultaba determinante adquirir el dominio de la cosa.

El desmesurado ámbito de aplicación que podrían recibir las causales de nulidad reseñadas se encuentra inevitablemente reñido con el texto del art. 1815, según el cual "la venta de cosa vale", norma que resultaría derogada en términos prácticos si se admitiera la posibilidad generalizada de anular la venta de cosa ajena ${ }^{97}$. El esfuerzo por subsumir la venta de cosa ajena en causales de nulidad tiende a desdibujar la regulación particular del contrato de compraventa, vaciándola de contenido, en base a la hipertrofia de categorías generales de la teoría del acto jurídico que no han sido concebidas para tratar en particular con la compraventa de cosa ajena. Resulta por lo mismo acertado que la Corte Suprema recientemente haya rechazado la aplicación de estas causales generales de nulidad a la venta de cosa ajena, negando, por ejemplo, que sea nula por falta de voluntad del dueño la compraventa suscrita con suplantación de identidad ${ }^{98}$ o celebrada en virtud de un mandato

\footnotetext{
89 Véase Alessandri (2003) tomo I vol. I, pp. 20-21, 227-228; De la Maza y Torres (2015) pp. 800-801. En materia jurisprudencial véase MICROSOFT CORPORATION CON LOPEZ (2008).

90 Garcia y Albornoz con Navarrete y BANCo SANTiago (2001), comentado por De la Maza y Torres (2015) pp. 801-802.

91 Para la doctrina española en este punto véase Fernández (1994) pp. 171-241.

92 De la Maza y Torres (2015) p. 797, citando al efecto SAAVEDRA CON N.N. (1996) y VALDÉS CON BORQUEZ (2005).

93 Véase Fernández (2018) pp. 77-78 y 139-159 para el tratamiento diferenciado en España del llamado falsus procurator, mostrándose él mismo crítico de la nulidad en este caso (pp. 146-150). Una distinción de este tipo fue descartada desde hace décadas en Chile, como se lee en Domínguez (1977) pp. 24-34.

94 Domínguez et al. (1995) pp. 186-187; Alessandri (2010) tomo I, pp. 389-392 y 403-407. Entre la jurisprudencia reciente véase FUENZALIDA CON FUENZALIDA (2015), considerando 30.

95 Véase Alessandri (2010) tomo I, pp. 404-405.

96 De la Maza y Torres (2015) pp. 801-803. Véase asimismo Domínguez (1979) pp. 12 y 22-23.

97 En el mismo sentido Fernández (2018) pp. 237-238, a propósito del supuesto de error.

98 PeÑa CON SANHUeza (2011).
} 
terminado $^{99}$, o que la doble venta de una misma cosa sea nula por tener causa ilícita ${ }^{100}$, privilegiándose en estos casos la norma específica del art. $1815^{101}$.

En este punto cabe advertir que las diversas teorías sobre las causales de nulidad aplicables a la venta de cosa ajena fueron formuladas por la doctrina francesa ${ }^{102}$. Considerando que se trata de soluciones formuladas al alero de un código que consagra como regla general la nulidad de la venta de cosa ajena, no es de extrañar que estas causales de nulidad estén llamadas a proyectarse sobre toda forma de venta de cosa ajena, teniendo por ello un ámbito de aplicación desmesurado al ser trasplantadas al Código Civil chileno, donde la validez de la venta de cosa ajena es la regla general.

Otra razón para negar la procedencia de estas hipótesis generales de nulidad (al menos para efectos de la nulidad absoluta) tiene que ver con la posibilidad de que la enajenación sea ratificada por el dueño ${ }^{103}$, como establece expresamente el art. 1818, confiriéndosele así retroactivamente los derechos respectivos al comprador desde la fecha de la venta, norma que encuentra su equivalente en materia de tradición en el art. 672 inc. $2^{\circ}$. Además, el art. 1819 regula la convalidación de la enajenación en virtud de la posterior adquisición del vendedor, lo cual tiene su paralelo en el ámbito de la tradición en el art. 682 inc. $2^{\circ}$. Esta posibilidad de subsanar el defecto inicial en la transmisión de la propiedad sería inadmisible en el caso de encontrarnos frente a un supuesto de nulidad absoluta (art. 1683). En este contexto, afirmar la nulidad generalizada de la venta de cosa ajena no solo contradice la regla especial del art. 1815, sino que implicaría dejar en una mayor desprotección al comprador, impidiéndole adquirir la propiedad por ratificación o convalidación ${ }^{104}$. Con ello se socavaría, por ejemplo, la posibilidad que un vendedor citado busque llegar a acuerdo con el tercero a fin de evitar las gravosas consecuencias que se siguen de la evicción según el art. 1847. Por lo demás, la nulidad también traería consigo una mayor debilidad del comprador desde el punto de vista de la prescripción adquisitiva, ya que no tendría un justo título (art. 704 No 3) y solo podría adquirir el dominio en virtud de la prescripción extraordinaria. De esta forma, si lo que se persigue es atender a la posición del comprador, la sanción de nulidad tiene el efecto inverso. Por lo mismo, no es raro que en la práctica sea quien se pretende dueño de la cosa -y no el comprador- quien persigue que se declare la nulidad de la venta, ya que ello le permite someter al comprador a plazos de prescripción más largos.

\subsection{INCUMPLIMIENTO CONTRACTUAL FUERA DEL RÉGIMEN DE EVICCIÓN}

Parte de la doctrina también ha afirmado que, si bien el Código Civil no establece que el vendedor está obligado a transferir la propiedad, en ciertos casos podría entenderse que la buena fe le impondría esta obligación. Este sería el caso cuando el vendedor entrega un objeto que no le pertenece, ocultando esta circunstancia al comprador, formulándose

\footnotetext{
99 FUENZALIDA CON FUENZALIDA (2015).

100 GALVEZ CON VALLS (2015).

101 De forma inconsistente, sin embargo, se afirmó en MICHELL CON MICHELL (2018) la falta de consentimiento en la compraventa celebrada en representación de una sociedad disuelta.

102 FERnÁNDEZ (1994) pp. 44-47.

103 Domínguez (1979) p. 23; Alessandri (2010) tomo I, pp. 405-406.

104 Véase en este sentido MARTÍNEZ CON MARTÍNEZ (1996). En el mismo sentido Fernández (2018) pp. 145-146.
} 
diversos parámetros para determinar cuándo sería procedente la responsabilidad del vendedor. Por ejemplo, Díez-Picazo aplica este supuesto de responsabilidad a casos en que al vendedor "le constaba o debía constarle, que el comprador había actuado sobre la base de la confianza de adquirir el dominio", así como en los supuestos en que le conste o deba constarle "que las finalidades económicas pretendidas por el comprador solo pueden conseguirse convirtiéndose en propietario de la cosa comprada" ${ }^{105}$. En el ámbito nacional, De la Maza y Torres consideran que se verificaría una conducta que daría lugar a responsabilidad contractual en virtud de la buena fe cuando el comprador ignore que la cosa sea ajena, cuando el vendedor le oculte esta circunstancia y cuando se haya integrado al contrato la presuposición de que la cosa sería propiedad del vendedor ${ }^{106}$.

El caso en que el vendedor debe responder contractualmente por la entrega deliberada de una cosa ajena encuentra un paralelo inmediato en el derecho romano, compartiendo en principio el mismo fundamento normativo: la infracción a la bona fides ${ }^{107}$. Sin embargo, existe una importante diferencia respecto al derecho clásico, como es la posibilidad de adquirir por prescripción adquisitiva: mientras en Roma la entrega deliberada de cosa ajena configuraba un supuesto de furtum que excluía la usucapión, en el sistema del Código Civil la mala fe del vendedor por lo general no juega un rol relevante para efectos de la posibilidad del comprador de adquirir por prescripción adquisitiva. Al no verificarse una desprotección del comprador desde el punto de vista de los derechos reales, no resulta igualmente justificado el recurso a la buena fe en derecho moderno para hacer procedente la responsabilidad del vendedor.

Lo dicho en el párrafo precedente no excluye que, en casos puntuales, la buena fe contractual sí pueda ser invocada para fundar una demanda de responsabilidad contra el vendedor. Debe recordarse que la buena fe objetiva tiene como función elemental sancionar la mala fe de los contratantes ${ }^{108}$. Para conseguir tal efecto, la buena fe permite integrar el texto del contrato, o incluso corregir soluciones generales del ordenamiento jurídico cuando ellas lleven a soluciones injustas ${ }^{109}$. En materia de venta de cosa ajena, de conformidad a lo señalado anteriormente, la corrección de las reglas generales en materia de obligaciones del vendedor podría resultar acertada cuando, como consecuencia de su actuar desleal y fraudulento, el comprador se encuentre en una situación de completa precariedad, en que protección a nivel de derechos reales o personales que le dispensa el ordenamiento jurídico sea en la práctica inoperante. Esto sucedería, por ejemplo, cuando el comprador ni siquiera esté en condiciones de gozar de la presunción de dominio del poseedor ${ }^{110}$. En estas circunstancias, resultaría

\footnotetext{
105 Díez-Picazo (2010) p. 59.

106 De la Maza y Torres (2015) pp. 810-811. Esta idea se expresa de forma menos acotada en De la MazA (2012) p. 654, Aburto y De la Maza (2015) p. 103 y Torres (2017) p. 305.

107 De la Maza y Torres (2015) p. 803.

108 Eyzaguirre y Rodríguez (2013) pp. 144-145; 178-184.

109 Eyzaguirre y Rodríguez (2013) pp. 184-200.

110 Salvando las peculiaridades del caso, resulta interesante a este respecto la jurisprudencia reseñada por ToRRES (2017) pp. 306-308 a propósito del régimen especial de los vehículos motorizados, donde se ha entendido que la mera entrega no satisface la obligación del vendedor, la cual comprende -en virtud de la buena fe- la inscripción en el registro respectivo, ya que ello permite al adquirente gozar de la presunción de dominio.
} 
excesivo exigir al comprador esperar una sentencia que lo prive de la cosa para demandar al vendedor, especialmente ante la nula expectativa de éxito de su defensa ${ }^{111}$, por lo que la buena fe parece llamada a cumplir una función relevante al permitir al comprador hacer valer la responsabilidad contractual del vendedor que ha actuado de mala fe aun antes que se verifique la evicción. En todo caso, correcciones de esta índole deben aplicarse de forma residual y en casos extremos, ya que incluso en situaciones de fraude la norma del artículo 1843 normalmente permitirá hacer responsable al vendedor de mala fe debido a su no comparecencia en juicio, lo que reduce sustancialmente la dimensión práctica del problema.

Para finalizar el tratamiento de las hipótesis de incumplimiento, se debe tener presente que el régimen general que ofrece el Código Civil no obsta a que el comprador prefiera no cargar con el riesgo de la eventual reclamación de un tercero, pudiendo convenir con el vendedor que este último se obligue a transferir el dominio ${ }^{112}$. Una compraventa celebrada en estos términos permitirá que el comprador demande la responsabilidad contractual del vendedor cuando se entere que se trata de una cosa ajena, sin tener que esperar que el verdadero dueño entre en escena. Para realzar la relevancia de contratar en estos términos, De la Maza y Torres indican que esta solución podría extrapolarse de diversas sentencias que han identificado un incumplimiento contractual cuando la cosa vendida tiene determinados vicios jurídicos, como encontrarse gravada con derechos reales en favor de terceros, en circunstancias que el vendedor se había obligado a entregar la cosa libre de $\operatorname{cargas}^{113}$.

Si bien es indudable que una compraventa celebrada en estos términos relevaría al comprador de tener que cargar con una virilis defensio para hacer valer la responsabilidad del vendedor, no puede dejar de observarse que obligar al vendedor a transferir la propiedad es menos urgente que obligarlo a entregar la cosa libre de gravámenes. La diferencia radica precisamente en la diversa protección que se le dispensa al comprador en cada caso en términos de derechos reales: en el primer caso el comprador puede consolidar su situación por medio de la prescripción adquisitiva, mientras que en el segundo caso la extinción del derecho real de un tercero es una mera eventualidad. En efecto, la prescripción adquisitiva no permite sanear los diversos derechos reales distintos del dominio sobre la cosa entregada por el mero paso del tiempo, y solo en ciertos casos particulares puede el titular del derecho real ver extinto su derecho ${ }^{114}$. Así, el adquirente que reciba la cosa sometida a usufructo, servidumbre, hipoteca o cualquier otro gravamen real, no podrá contar con que el transcurso de un plazo específico a partir de la adquisición de la cosa extinga los derechos del tercero sobre la cosa, lo que hace más gravitante la posibilidad de contar con acciones personales contra el vendedor. Queda así descartada la posibilidad de un tratamiento conjunto de ambas situaciones, que suelen por lo mismo ser abordadas separadamente en la experiencia comparada ${ }^{115}$.

\footnotetext{
111 WACKE (1992) p. 203: "Hoy por hoy, caso de existir un derecho manifiesto por parte de un tercero, sería inaceptable obligar al comprador a entablar un proceso contra el tercero sin ninguna expectativa de éxito para él”. 112 Alessandri (2003) tomo I vol. II, p. 30; De la Maza (2012) p. 653; De la Maza y Torres (2015) pp. 806-809.

113 De la Maza (2012) pp. 656-657; De la Maza y Torres (2015) pp. 806-809, donde se analizan SILVA CON Dosque (1993); Sociedad de TRANSPORTES Quillaicillo con Contreras (2009); Sin identificaCión DE PARTES (2007). En el mismo sentido De la MaZa (2017) p. 376.

114 Véase por ejemplo los arts. 885 No 5 y 2434.

115 Véase Fernández (2018) pp. 293-299.
} 


\section{CONCLUSIONES}

En base al análisis histórico-comparativo aquí desarrollado, podemos concluir que las soluciones ofrecidas por diversos sistemas jurídicos en materia de venta de cosa ajena descansan sobre la interacción entre las esferas de derechos reales y personales. En el derecho romano, el comprador de cosa ajena contaba no solo con la posibilidad de usucapir, sino que también con diversas defensas que debía hacer valer, en colaboración con el vendedor, como presupuesto para demandar al vendedor con la actio empti. Esta relación de colaboración fue alterándose conforme varió la protección real del vendedor, especialmente con la imposición de la regla mala fides superveniens nocet y con el reconocimiento en determinados sistemas jurídicos la posibilidad de adquirir a non domino. Ello a su vez llevó a consagrar en diversos sistemas jurídicos la nulidad de la venta de cosa ajena (particularmente en los sistemas de enajenación consensual) o la obligación del vendedor de transferir el dominio, eliminando al mismo tiempo la exigencia de una virilis defensio como presupuesto para hacer valer la responsabilidad del vendedor.

Al consagrar una virilis defensio, el Código Civil chileno propende efectivamente a la colaboración entre los contratantes tendiente a que la protección real del comprador sea eficaz y que la responsabilidad del vendedor sea justificada, dandole a este último un poderoso incentivo para defender al comprador de la mejor forma. Frente a esto, imponer una obligación de transferir el dominio no solo desarticula una defensa conjunta, sino que hace responder al vendedor por cualquier alegación mínimamente plausible de un tercero, imposición que resulta especialmente gravosa en los sistemas que -como el chileno- no consagran una norma general de adquisición a non domino. Por otra parte, el comprador en Chile no se encuentra desprotegido frente a situaciones de abuso o fraude, pudiendo hacer valer la responsabilidad del vendedor por su mala fe por medio de las normas generales sobre buena fe contractual. Por todo lo anterior, consideramos que no resulta deseable modificar la regulación del Código Civil en la materia, y que debe rechazarse la posibilidad de alegar de forma genérica la nulidad o el incumplimiento contractual para atender a la posición del comprador, ya que ello resulta contrario no solo al texto legal, sino que a la mecánica que subyace a las soluciones del Código Civil.

\section{BIBLIOGRAFÍA CITADA}

Aburto, Juan Pablo y De la Maza, Iñigo (2015): "Falta de conformidad jurídica y tutela del comprador", Revista Ius et Praxis, vol. 21, No 2: pp. 61-108.

AEdo, Cristián (2015): “¿Cuál es el contenido de la obligación de entrega del vendedor en el Derecho Chileno”, en Henríquez, Ian (coord.), La Compraventa, Nuevas perspectivas doctrinarias (Santiago, Thomson Reuters) pp. 5-42.

Alessandri Besa, Arturo (2010): La nulidad y la Rescisión en el Derecho Civil Chileno (Santiago, Editorial Jurídica de Chile).

Alessandri Rodríguez, Arturo (2003): De la compraventa y de la promesa de venta (Santiago, Editorial Jurídica de Chile).

BARCIA, Rodrigo (2010): Lecciones de derecho civil chileno. Tomo II De las fuentes de las obligaciones (Santiago, Editorial Jurídica de Chile). 
Bergmann, Andreas (2010): "Die Theorie der Rechtsmängelhaftung:- Rechtsverschaffungsprinzip, habere licere und Eviktionshaftung", Rabels Zeitschrifht für ausländisches und internationales Privatrecht, vol. 74, No 1: pp. 25-90.

Cárdenas, Hugo y Reveco, Ricardo (2018): Remedios contractuales, Cláusulas, acciones y otros mecanismos de tutela del crédito (Santiago, Thomson Reuters).

CATTÁn, Ángela (1982): "Fuentes romanas "De la cosa vendida" en el Código Civil chileno", en Homenaje a Don Andrés Bello (Santiago, Editorial Jurídica de Chile) pp. 613-624.

CRISTALDI, Salvatore (2007): Il contenuto dell'obbligazione del venditore nel pensiero dei giuristi dell'età imperiale (Milán, Giuffrè Editore).

De la Maza, Iñigo (2012): "El régimen de los cumplimientos defectuosos en la compraventa", Revista Chilena de Derecho, vol. 39, No 3: pp. 629-663.

De la Maza, Iñigo y Torres, Ricardo (2015): "La protección del comprador en la venta de cosa ajena”, Revista Chilena de Derecho, vol. 42, No 3: pp. 785-818.

De la MaZA, Iñigo (2017): "El supuesto de hecho de la evicción: perturbaciones", en DE la Maza, Iñigo y Contardo, Juan Andrés (edit.), La Compraventa, Estudios (Santiago, Thomson Reuters) pp. 349-379.

De la Maza, Iñigo y Pizarro, Carlos y Vidal, Álvaro (2017): Los Principios Lationamericanos de Derecho de los Contratos (Madrid, Boletín Oficial del Estado).

De la MazA, Iñigo y VIDAL, Álvaro (2018): Cuestiones de derecho de contratos (Santiago, Thomson Reuters).

Díez-PICAzo, Luis (2010): Fundamentos del derecho civil patrimonial, tomo IV: Las particulares relaciones obligatorias (Cizur Menor Navarra, Thomson Reuters).

Domínguez Águila, Ramón (1977): Negocios jurídicos sobre cosa ajena (Concepción, Facultad de Ciencias Jurídicas y Sociales).

Domínguez Águila, Ramón et al. (1995): “Comentarios de jurisprudencia”, Revista de Derecho Universidad de Concepción, No 198: pp. 183-189.

ERnst, Wolfgang (1995): Rechtsmängelhaftung (Tubinga, Mohr Siebeck).

Eyzaguirre, Cristóbal y Rodríguez, Javier (2013): “Expansión y límties de la buena fe objetiva - a propósito del 'Proyecto de Principios Latinoamericanos de Derecho de los Contratos'", Revista Chilena de Derecho Privado, No 21: 137-216.

FERnÁndez, María del Carmen (1994): Compraventa de cosa ajena (Barcelona, Bosch).

FERnÁndeZ, Ignacio (2018): La transmisión de la propiedad en la compraventa (Cizur Menor, Thomson Reuters Aranzadi).

GuIDA, Giovanni (2013): La tutela del compratore in caso di evizione fra garanzia e responsabilità (Nápoles, Jovene).

Hijma, Jacob (2007): Mr. C. Asser's Handleiding tot de beoefening van het Nederlands burgerlijk recht, Bijzondere overeenkomsten, vol. 1: Koop en Ruil (Deventer, Kluwer, $7^{\circ}$ edición).

Magnus, Ulrich (2010): "Art. 41 [Rechtsmängel]", en Honsell, Heinrich (edit.), Kommentar zum UN-Kaufrecht (Heidelberg, Springer) pp. 443-450.

Morales, Antonio (2017): "Adaptación del Código Civil al derecho europeo: La compraventa", en De la Maza, Iñigo y Contardo, Juan Andrés (edit.), La Compraventa, Estudios (Santiago, Thomson Reuters) pp. 11-58. 
Petronio, Ugo (1991): "Vendita, trasferimento della proprietà e vendita di cosa altrui nella formazione del Code civil e dell' Allgemeines Buergerliches Gesetzbuch”, en VACCA, Letizia (edit.), Vendita e trasferimento della proprietà nella prospettiva storico-comparatistica, Volumen I (Milán, Giuffrè) pp. 169-195.

Rabel, Ernst (1936): Das Recht des Warenkaufs, Einge rechtsvergleichende Darstellung (Berlín, De Gruyter).

RodrígueZ, Maximiliano (2011): "La obligación de entregar mercaderías libres de derechos o pretensiones de terceros en la Convención de Viena de 1980 sobre Compraventa Internacional", Revista e-mercatoria, vol. 10: pp. 1-30.

RodríGUEZ, Javier (2016): Potestas alienandi, transfer of ownership by a non-owner from Roman law to the DCFR (Oisterwijk, Wolf Legal Publishers).

Salinas, Carlos (2004): "Un influjo frustrado del derecho canónico en el Código Civil de Chile: 'mala fides superveniens nocet'", Revista de Estudios Histórico-Jurídicos, vol. 26: pp. 471-489.

Schlechtriem, Peter (1984): “The Seller's Obligations Under the United Nations Convention on Contracts for the International Sale of Goods". Disponible en: https:// cisgw3.law.pace.edu/cisg/biblio/schlechtriem10.html. Fecha de consulta: 10 de febrero de 2019.

STAGL, Jakob Fortunat (2011): “Gutgläubiger Fahrniserwerb als 'sofortige Ersitzung' Eine Neubestimmung der $\$ \$ 932$ ff. BGB”, Archiv für die civilistische Praxis, vol. 211: pp. 530-582.

STAGL, Jakob Fortunat (2016): "La transferencia de la propiedad en la compraventa de bienes muebles en el derecho privado europeo (DCFR y CESL)", Revista Chilena de Derecho Privado, No 26: pp. 231-268.

Torres, Ricardo (2017): "La extensión de la obligación de entrega con cargo a la buena fe objetiva: criterios jurisprudenciales", en De la Maza, Iñigo y Contardo, Juan Andrés (edit.), La Compraventa, Estudios (Santiago, Thomson Reuters) pp. 285-317.

Troncoso, Hernán y Álvarez, Carlos (2014): Contratos (Santiago, Thomson Reuters).

UGarte Godoy, Joaquín (1970): "La obligación esencial del vendedor es transferir el dominio", en Mc Hale, Tomás y Del Valle, Jaime (edit.), Estudios en Honor de Pedro Lira Urquieta (Santiago, Editorial Jurídica de Chile) pp. 151-193.

VACCA, Letizia (2010): "La garanzia per evizione e le obbligazioni del venditore nel sistema romano e nel sistema del codice civile italiano", en VACCA, Letizia, Garanzia e responsabilità, concetti romani e dogmatiche attuali (Padua, Cedam) pp. 1-39.

VIDAL, Álvaro (2017): "La protección del comprador en el Código Civil”, en De la MAZA, Iñigo y Contardo, Juan Andrés (edit.), La Compraventa, Estudios (Santiago, Thomson Reuters) pp. 233-284.

WACKE, Andreas (1992): "Los presupuestos de la responsabilidad por evicción en derecho romano y en derecho comparado", Seminarios Complutenses de Derecho Romano, vol. IV, pp. 157-204.

Zimmermann, Reinhard (1996): The Law of Obligations (Oxford, Clarendon Press). 


\section{JURISPRUDENCIA CITADA}

FUENZALIDA CON FUENZALIDA (2015): Corte Suprema 23 de marzo de 2015 (Venta con mandato terminado) cita Westlaw CL/JUR/1666/2015.

GALVEZ CON VALLS (2015): Corte Suprema, 7 de mayo de 2015 (Venta sucesiva a dos compradores distintos) cita Westlaw CL/JUR/2477/2015.

García y Albornoz con NavarRete y Banco Santiago (2001): Corte Suprema, 30 de mayo de 1999 (nulidad en venta por pública subasta) cita Westlaw CL/JUR/1504/2001.

MARTÍNEZ CON MARTÍNEZ (1996): Corte de Apelaciones de Santiago, 17 de enero de 1996 (Venta con mandato revocado) Revista de Derecho y Jurisprudencia, tomo 93 (1996), I, sección 2da, pp. 8-20.

MiCHeLl CON MiCHeLl (2018): Corte Suprema 6 de agosto de 2018 (Venta en representación de sociedad disuelta) cita MicroJuris MJCH_MJJ56722.

Microsoft Corporation con López (2008): Corte de Apelaciones de Santiago, 3 de octubre de 2008 (Objeto ilícito y venta de cosa ajena) cita Westlaw CL/JUR/6112/2008.

PENA CON SANHUEZA (2011): Corte Suprema, 25 de noviembre de 2011 (Venta con firma falsificada), cita MicroJuris MJCH_MJJ30312.

SAAVEDRA CON N.N. (1996): Corte Suprema, 29 de abril de 1996 (Venta concluida por mandato nulo) cita Westlaw CL/JUR/406/1996.

Silva con Dosque (1993): Corte de Apelaciones de Concepción, 1 de diciembre de 1993 (Venta de bien gravado) cita Westlaw CL/JUR/66/1993.

SIN IDENTIFICACIÓN DE PARTES (2007): Corte de Apelaciones de Santiago 10 de julio de 2007 (Venta de bien prendado), cita Westlaw CL/JUR/1338/2007.

Sociedad de Transportes Quillaicillo con Contreras (2009): Corte Suprema 22 de septiembre de 2009 (Venta de bien prendado) cita Westlaw CL/JUR/1235/2009.

Toro CON BANCo SANTANDER ChILE (2011): Corte Suprema, 26 de Septiembre de 2011 (Obligaciones del vendedor y error de deslindes) cita Westlaw CL/JUR/9809/2011.

VALDÉS CON BÓRQUEZ (2005): Corte de Apelaciones de Antofagasta, 2 de noviembre de 2005 (Venta concluida con mandato falsificado) cita Westlaw CL/JUR/4558/2005. 